\title{
A Diagnostic Test to Measure Students Physics Data Literacy Skills During the Covid-19 Pandemic
}

\author{
Maria Enjelina Suban ${ }^{1, *}$ Supahar $^{2,}$ Endah Kartika ${ }^{1,}$ Zulaikha Ummul Arafah ${ }^{1}$ \\ ${ }^{1}$ Master of Physics Education, Faculty of Mathematics and Natural Sciences, Universitas Negeri Yogyakarta, \\ Indonesia \\ ${ }^{2}$ Department of Physics Education, Faculty of Mathematics and Natural Sciences, Universitas Negeri Yogyakarta, \\ Indonesia \\ ${ }^{*}$ Corresponding author. Email: angelsuban27@gmail.com
}

\begin{abstract}
The industrial revolution 4.0 and the COVID-19 pandemic that hit Indonesia requires all elements of education to apply online-based learning. The existence of information technology really supports the continuity of online learning. One of the supporting factors is data literacy ability. The assessment instrument diagnostic is important in providing information related to students' data literacy skills. This study aims to determine the suitability of an instrument in providing the expected information. The feasibility of the instrument includes the validity, reliability, and difficulty of each item. This test instrument consists of 6 indicators with 5 alternative answers. The test was conducted on 71 students of the MIPA Class. The validity of the instrument content was analysed using the Aiken $\mathrm{V}$ equation, while the empirical validity, the difficulty level of the items, and the reliability of the instrument were analysed using the QUEST program. The results of the analysis show that the validity of the instrument content and the empirical validity of the instrument are valid and reliable. Test instruments can be applied to students with low to high abilities. In general, the percentage of measurement results shows that the average data literacy ability of students is moderate.
\end{abstract}

Keywords: Test instrument, Diagnostic, Data literacy, Physics, Pandemic, COVID-19.

\section{INTRODUCTION}

Technological advances in the period industrial revolution 4.0 have influenced various sectors of life. In Indonesia, the adjustment of life in the era of the industrial revolution 4.0 still has to be improved [1]. The world of education is expected to be able to face this challenge. Since mid-March, Indonesia has reportedly been affected by the corona virus pandemic, known as COVID-19. COVID-19 can attack every individual with a very fast chain of transmission. The impact of this pandemic is expected to be long-lasting [2][3]. The government's way of minimizing the impact in terms of the education sector is by implementing online learning [4][5]. Educators and students must be able to use network and information technology [6]. This method is expected to balance the effectiveness of traditional and online teaching patterns. The challenge is to implement online learning that has never been implemented and to improve the quality of education.

The assurance of the quality of education is inseparable from a good learning process. Learning outcomes are strongly influenced by several aspects. One important aspect is assessment [7][8]. A good assessment is that which provides diagnoses and suggestions for updates to students [9]. This type of assessment is called a diagnostic assessment. The scoring system is to diagnose the student's ability on each item of the problem and will be given further treatment in the form of suggestions [10]. This diagnostic test provides an overview for educators and students to re-evaluate learning outcomes on the material that has been obtained. In contrast to other types of assessment in general, diagnostic assessments emphasize the achievement of learning completeness to reduce the occurrence of misconceptions in subsequent learning [11].

Technological advances have brought the field of assessment that was originally traditional to an online system [12]. The benefits of online assessment are to anticipate if there are obstacles to traditional learning, it is more effective, and makes it easier for educators to work [12]. The existence of an assessment can be a guide in providing input on the weaknesses that occur in 
students during learning [7]. Evaluation activities require tools in the form of assessment instruments. A good assessment instrument includes the validity, reliability, and reliability of the assessment instrument in expressing students' latent abilities [13][14]. One of the abilities that need to be evaluated at this time is data literacy skills.

The development of network and information technology has increasingly attracted the attention of educational practitioners. The challenge of mastering big data is needed [15][16]. In the school of physics studied to find out natural phenomena in life [17]. Various kinds of experiments and practicums were carried out to make it easier for students to master the concepts of physics. The first step that needs to be done is to hone data literacy skills [18]. Data literacy helps students in determining the purpose of using data, finding sources of data or accurate information, processing, and processing data appropriately, and being able to infer information based on data [19] [20] [21]. The lack of student data literacy knowledge affects the learning process. This is in line with Bhargava's opinion which states those students' data literacy skills have not developed well [21]. It is necessary to analyze data literacy indicators [19] [20] [21] as in Table 1 which is obtained from the synthesis of several articles.

Table 1. Results of the synthesis of data literacy Indicators

\begin{tabular}{|c|c|c|}
\hline \multicolumn{3}{|l|}{ Data Literacy } \\
\hline Aspects & Sub-aspects & Indicators \\
\hline \multirow[t]{2}{*}{ Data } & $\begin{array}{c}\text { Data source } \\
\text { accuracy }\end{array}$ & $\begin{array}{l}\text { Students can } \\
\text { determine the } \\
\text { accuracy of the } \\
\text { data source }\end{array}$ \\
\hline & $\begin{array}{c}\text { Selects related } \\
\text { variables based } \\
\text { on data }\end{array}$ & $\begin{array}{c}\text { Students can } \\
\text { choose the data } \\
\text { variables used }\end{array}$ \\
\hline Analyze Data & Analyze data & $\begin{array}{c}\text { Students can } \\
\text { analyze data } \\
\text { based on physics } \\
\text { concepts }\end{array}$ \\
\hline \multirow[t]{2}{*}{$\begin{array}{c}\text { Interpreting } \\
\text { Data }\end{array}$} & $\begin{array}{l}\text { Interpret data } \\
\text { into graphs }\end{array}$ & $\begin{array}{l}\text { Students can } \\
\text { study charts }\end{array}$ \\
\hline & $\begin{array}{l}\text { Interpret data in } \\
\text { mathematical } \\
\text { form }\end{array}$ & $\begin{array}{c}\text { Students can } \\
\text { interpret the data } \\
\text { in a mathematical } \\
\text { form }\end{array}$ \\
\hline
\end{tabular}

\begin{tabular}{|c|c|c|}
\hline \multicolumn{3}{|l|}{ Data Literacy } \\
\hline Aspects & Sub-aspects & Indicators \\
\hline Make & Formulate & Students can \\
Conclusions & conclusions & formulate \\
Based on Data & based on the & appropriate \\
& data format & conclusions \\
& & based on data \\
\hline
\end{tabular}

One of the physics materials that apply data literacy skills a lot is momentum and impulse [22]. Momentum and impulse are materials that study the collision phenomenon. The collisions that occur can have values and directions which are usually expressed in the graphical form [17]. This material involves a lot of a series of experiments or practicums that need data literacy skills.

\section{RESEARCH METHOD}

This study uses a quantitative approach. The sample of this research was 71 students of class X MIPA 1 and X MIPA 2 SMA Negeri 1 Prambanan. The research was conducted online using google form. To take the test, students must fill in their full name, attendance number, and class. The execution of the test questions is carried out following the time stipulated on the Google form. The stages of developing a data literacy test instrument refer to the development models of Thiagarajan [23] and Mardapi. The test developed was adjusted to the 2013 curriculum on Impulse and Momentum material for SMA Negeri 1 Prambanan. The test instrument used to measure students' data literacy skills consisted of 12 items with 5 alternative answers. The test instrument development procedure can be seen in Figure 1.

The assessment instrument was validated by 4 experts. The validation sheet consists of the material, construction, and language aspects which in total has 13 indicators. The feasibility of the assessment instrument for the empirical test obtained the validation results. For the empirical test obtained the validation results. These results then use the Aiken V Equation (1) as follows [24].

$$
\mathrm{v}=\frac{\sum \mathrm{s}}{[\mathrm{n}(\mathrm{c}-1)]}
$$

The Aiken $\mathrm{V}$ equation consists of $\mathrm{s}$ which is the result of $\left(r-l_{o}\right)$. The symbol $r$ is the number given by the validator while $l_{o}$ is the lowest validity number. The symbol $n$ is the number of validators and $c$ is the highest validity number. The results of validation by 


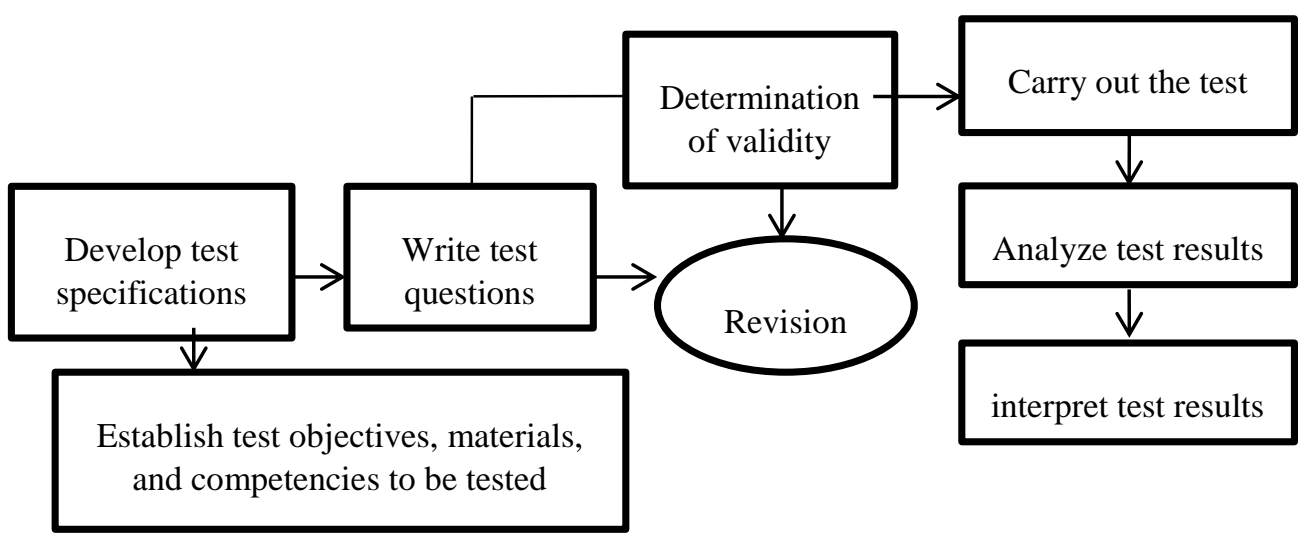

Figure 1 Stages of development of test instrumen

experts are then categorized in the Aiken $\mathrm{V}$ index range. If the Aiken $\mathrm{V}$ index is less than 0.4 it is categorized as low, between $0.4-0.8$ moderate, and more than 0.8 is categorized as very high.

The empirical test involved 71 students consisting of 36 students of class X MIPA 1 and 35 students of class X MIPA 2. The analysis in testing used the classical theory approach and item response theory (IRT) to see the validity of the test questions, the level of difficulty of each question, the reliability of the question instruments, and the question of information function. In the QUEST program, an item is declared valid if the INFIT MNSQ value ranges from 0.77 to 1.30 [25]. The IRT analysis was adjusted to the Rasch model, namely the one-parameter logistic (PL) model. This parameter that determines the level of student ability is seen from the difficulty level of the items. According to the Rasch model, the item is said to be good if the difficulty level is in the range of -2.00 to +2.00 . The reliability of the test instrument is determined based on the alpha cronbrach coefficient. If the alpha cronbrach coefficient is $\geq 0.87$, it can be said that the instrument is suitable or can be trusted to provide the expected information. To complete the results of the reliability analysis, item information functions are needed. The item information function is used to explain the strength of the test items in providing information. The higher the information function of the test items, the more reliable the test items are in expressing the expected information. Estimation of the information function in the IRT often experiences measurement uncertainty. Therefore, the measurement standard error of measurement (SEM) needs to be done to produce accurate information functions.
Table 2. Rating Category

\begin{tabular}{|c|c|}
\hline Percentage (\%) & Category \\
\hline $80-100$ & Very High \\
\hline $60-79$ & High \\
\hline $40-59$ & Moderate \\
\hline $20-39$ & Low \\
\hline $0-19$ & Very Low \\
\hline
\end{tabular}

The percentage of students' data literacy ability scores was analyzed based on the output estimate from the analysis using the QUEST program. The output is then converted into a T score. The T score Equation (2) used is as follows:

$$
\text { T score }=10(\text { estimate })+50
$$

The $\mathrm{T}$ score is categorized based on the ranking of data literacy abilities. Categorization of the level of data literacy ability assessment can be seen in Table 2 .

\section{RESULT AND DISCUSSION}

\subsection{Results of The Test Question Grid}

The item grid is arranged when the objectives for the test are set, the material is determined, and the competencies to be tested. The test question grid consists of 5 aspects, 6 sub aspects, 6 question indicators, 20 test questions with 5 alternative answers, a description of the answers, answer keys, diagnosis, and advice.

\subsection{Results of Test Items}

The results of the test items are 20 items from the 6 question indicators. The questions were then given to 4 experts to be assessed. The aspects assessed include material, construction, and language aspects. 


\subsection{Results of The Test Instrument Validity Assessment}

The 20 questions were arranged and then validated. The validation results showed that there were 12 items that were declared valid based on the material, construction, and language aspects by 4 experts. Table 3 shows the results of the validity analysis of 12 items based on Aiken V.

Table 3. Results of the validity analysis of test instruments by experts

\begin{tabular}{|c|c|c|}
\hline Item Number & Aiken Value & Decision \\
\hline 1 & 0,88 & Very High \\
\hline 2 & 0,81 & Very High \\
\hline 3 & 0,88 & Very High \\
\hline 4 & 0,88 & Very High \\
\hline 5 & 0,94 & Very High \\
\hline 6 & 0,94 & Very High \\
\hline 7 & 0,94 & Very High \\
\hline 8 & 1,00 & Very High \\
\hline 9 & 0,94 & Very High \\
\hline 10 & 0,94 & Very High \\
\hline 11 & 0,88 & Very High \\
\hline 12 & 0,88 & Very High \\
\hline
\end{tabular}

Data from the analysis of the validity of the test instrument by the expert shows that the test instrument to measure students' data literacy skills is valid and can be applied to empirical tests.

\subsection{Standardized Test Item Results}

There are 12 standardized or ready-to-use test items for the purposes of assessing students' data literacy abilities. Figure 2 is the result of writing the items using Google form.

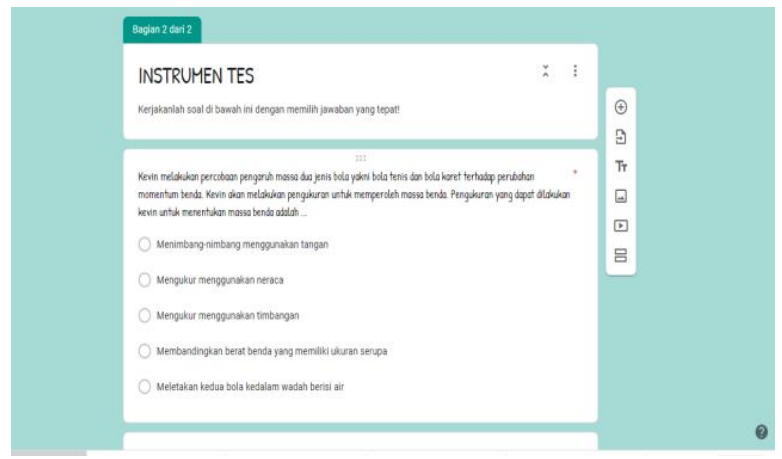

Figure 2 Results of writing question points from google form

\subsection{Results of The Validity and Reliability of the Empirical Test}

The results of the empirical validity test using the QUEST program are shown by the MNSQ INFIT value so that an average of 1.00 with a standard deviation of 0.18 is obtained. The average value is said to be valid because it is in the range of 0.77 to 1.30 which is following the Rasch model. Figure 3 shows the results of the analysis of each item based on the Fit model.

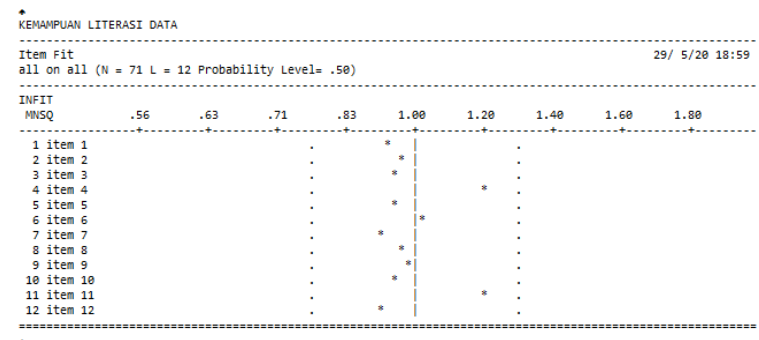

Figure 3 Rasch model test item compatibility

The difficulty index with the easy category is found at a value of -1.63 (question number 8) and the moderate difficulty index is at a value of 1.00 (question number 7). The index of the difficulty level of the data literacy test instrument is in the range -1.00 to 1.00 in the moderate category. If the item difficulty index -2.0 is classified as very easy while the difficulty index +2.0 is classified as very difficult [26]. Figure 4 shows the comparison of the difficulty level of each item.

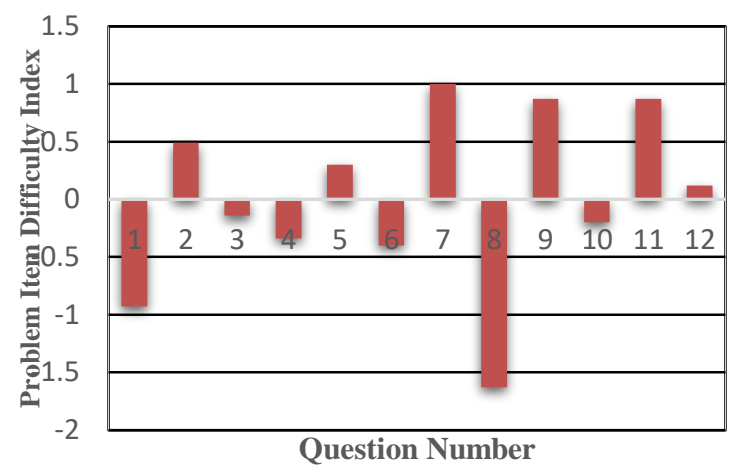

Figure 4 Level of difficulty for each item

The results of the reliability analysis of the data literacy test instrument showed the alpha conbrach coefficient of 0.87 . That is, the test instrument can be trusted to provide the expected information.

\subsection{Results of The Question Item Information Function and Standard Error of Measurement}

The results of the item information function curve analysis and measurement standard errors in the Parscale program are used to determine the reliability of 
the test instruments according to the IRT. The results of the analysis are shown in Figure 5.

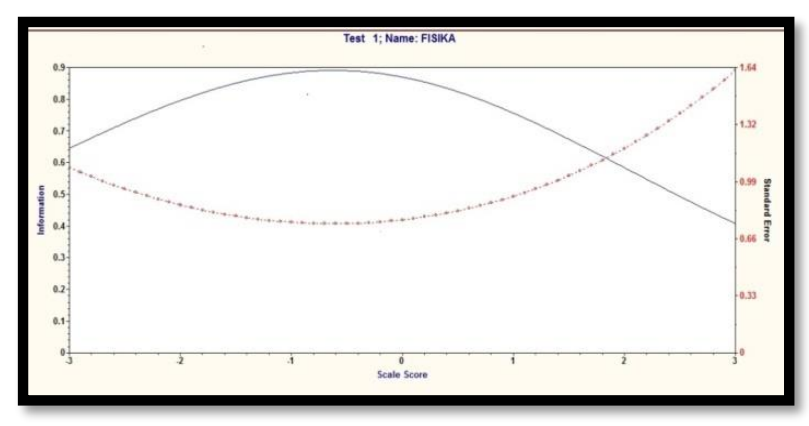

Figure 5 Item information curve and SEM

The information function of the total test items is 0.64 with a standard error of measurement of 0.66 . This means that the function of the test instrument to determine students' data literacy skills is suitable for students who have an ability of at least 0.64 with a low standard error of measurement. The level of reliability of the test instruments in measuring students' literacy skills ranges from -3 to +2 , as can be seen in Figure 6 .

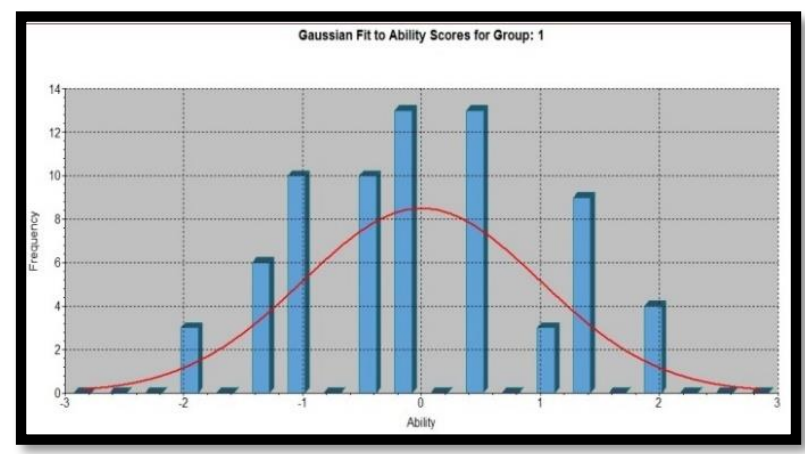

Figure 6 Histograms of the distribution of student data literacy abilities

Figure 6 shows students with a low ability level or close to -3 are less than students with moderate ability approaching +2 . This means that the test instrument can be used to measure students' data literacy skills. The level of students' data literacy skills can be seen in Table 4.

Table 4. Level of student's data literacy ability

\begin{tabular}{|c|c|c|}
\hline $\begin{array}{l}\text { Percentage of Ability } \\
(\%)\end{array}$ & $\begin{array}{l}\text { Total } \\
\text { Students }\end{array}$ & Category \\
\hline $80-100$ & 13 & Very High \\
\hline $60-79$ & 15 & High \\
\hline $40-59$ & 34 & Moderate \\
\hline $20-39$ & 9 & Low \\
\hline $0-19$ & 0 & Very Low \\
\hline
\end{tabular}

The estimation result of the analysis using the QUEST program shows that the number of students who have moderate ability is 34 people with a percentage range of $40 \%$ to $59 \%$. This number is more than any other ability level. This is because students have not been able to interpret data in various formats. A low understanding of concepts results in students being less able to analyze the data presented [27]. These results provide a reference that the data literacy skills of students at SMA Negeri 1 Prambanan need to be improved.

\section{CONCLUSION}

The results of the analysis of a diagnostic test that is suitable for use, are declared valid and reliable to measure students' data literacy skills. The level of students' data literacy skills is in the medium category and is more dominant than other ability levels. Therefore, the results of this analysis provide a reference that the data literacy skills of students at SMA Negeri 1 Prambanan need to be improved. Future research can apply a diagnostic assessment system to ascertain student weaknesses related to data literacy.

\section{AUTHORS' CONTRIBUTIONS}

The results of this study can be used as a guideline for teachers and advanced researchers in preparing valid and reliable diagnostic test questions in describing students' data literacy skills.

\section{ACKNOWLEDGMENTS}

Thanks to a number of parties who participated in the completion of this research.

\section{REFERENCES}

[1] A.A. Shahroom, N. Hussin, Industrial Revolution 4.0 and Education, International Journal of Academic Research in Business and Social Science 8(9) (2018) 314-319. DOI:

\section{https://doi.org/10.6007/ijarbss/v8-i9/4593}

[2] L.Y. Hsu, P.Y. Chia, S. Vasoo, A Midpoint Perspective on The COVID-19 Pandemic, Singapore Medical Jurnal 61(7) (2020) 381-383. DOI: https://doi.org/10.11622/smedj.2020036

[3] J. Cleland, J. McKimm, R. Fuller, D. Taylor, J. Janczukowicz, T. Gibbs, Adapting to The Impact of COVID-19: Sharing Stories, Sharing Practice, Medical Teacher 42(7) (2020) 772-775. DOI: https://doi.org/10.1080/0142159X.2020.1757635

[4] S. Dhawan, Online Learning: A Panacea in The Time of COVID-19 Crisis, Journal of Educational 
Technology Systems 49(1) (2020) 5-22. DOI: https://doi.org/10.1177/0047239520934018

[5] Y. Pujilestari, Dampak Positif Pembelajaran Online dalam Sistem Pendidikan Indonesia Pasca Pandemi Covid-19, ADALAH: Buletin Hukum \& Keadilan $4(1) \quad$ (2020) 49-56. DOI: https://doi.org/10.15408/adalah.v4i1.15394

[6] A.A. Hussin, Education 4.0 Made Simple: Ideas for Teaching, International Journal of Education and Literacy Studies 6(3) (2018) 92. DOI: https://doi.org/10.7575/aiac.ijels.v.6n.3p.92

[7] F. Kurnia, D. Rosana, Supahar, Developing evaluation instrument based on CIPP models on the implementation of portfolio assessment, in: International Conferences on Research, Implementation, and Education of Mathematics and Science, vol. 1868, AIP, College Park, Maryland, 2017, pp. 080003. DOI: https://doi.org/10.1063/1.4995187

[8] K. Moharreri, M. Ha, R.H. Nehm, EvoGrader: An Online Formative Assessment Tool for Automatically Evaluating Written Evolutionary Explanations, Evolution: Education and Outreach 7(1) (2014) $15 . \quad$ DOI: https://doi.org/10.1186/s12052-014-0015-2

[9] Soeharto, B. Csapó, E. Sarimanah, F.I. Dewi, T. Sabri, A Review of Students' Common Misconceptions in Science and Their Diagnostic Assessment Tools, Jurnal Pendidikan IPA Indonesia $\quad 8(2) \quad$ (2019) 247-266. DOI: https://doi.org/10.15294/jpii.v8i2.18649

[10] L. Rouweler, N. Varkevisser, M. Brysbaert, B. Maassen, W. Tops, The Flamingo Test: A New Diagnostic Instrument for Dyslexia in Dutch Higher Education Students, European Journal of Special Needs Education 35(4) (2020) 529-543. DOI:

https://doi.org/10.1080/08856257.2019.1709703

[11] A. Champagne Queloz, M. W. Klymkowsky, E. Stern, E. Hafen, K. Köhler, Diagnostic of Students' Misconceptions using The Biological Concepts Instrument (BCI): A Method for Conducting An Educational Needs Assessment, PLoS One 12(5) (2017) e0176906. DOI: https://doi.org/10.1371/journal.pone.0176906

[12] T.H. Wang, Developing An Assessment-Centered E-Learning System for Improving Student Learning Effectiveness, Computers and Education 73 (2014) 189-203. DOI: https://doi.org/10.1016/j.compedu.2013.12.002
[13] K. Bashooir, Supahar, Validitas dan Reliabilitas Instrumen Asesmen Kinerja Literasi Sains Pelajaran Fisika Berbasis STEM, Jurnal Penelitian dan Evaluasi Pendidikan 22(2) (2018) 168-181. DOI: https://doi.org/10.21831/pep.v22i2.20270

[14] Supahar, D. Rosana, Desemination of Authentic Assessment in Local Content-Based Sciences Learning to Achieve The Learning Outcomes based on Nature of Science, Journal of Physics: Conference Series, in: IOP Publishing, Bristol, 1097, 1, 2018, p. 012034. DOI: https:/doi.org/10.1088/17426596/1097/1/012034

[15] A.Y. Pedersen, F. Caviglia, Data literacy as a compound competence, in: Advances in Intelligent Systems and Computing, vol. 850, Springer, Switzerland, 2018, pp. 465-472. DOI: https://doi.org/10.1007/978-3-030-02351-5

[16] Y. Ying, Research on College Students' Information Literacy based on Big Data, Cluster Computing 22(2) (2019) 3463-3470. DOI: https://doi.org/10.1007/s10586-018-2193-0

[17] A. Widayoko, E. Latifah, L. Yuliati, Peningkatan Kompetensi Literasi Saintifik Siswa SMA dengan Bahan Ajar Terintegrasi STEM pada Materi Impuls dan Momentum, Jurnal Pendidikan: Teori, Penelitian, dan Pengembangan 3(11) (2018) 1463 1467.

DOI: https://doi.org/10.17977/jptpp.v3i11.11767

[18] W.Y. Lestari, D. Rosana, Analysis of Junior High School students' Data Literacy in Ciamis with Local Potential Kampung Adat Kuta, Journal of Physics: Conference Series 1440(1) (2020) $012097 . \quad$ DOI: https://doi.org/10.1088/17426596/1440/1/012097

[19] J.P. Gibson, T. Mourad, The Growing Importance of Data Literacy in Life Science Education, American Journal of Botany 105(12) (2018) 1953 1956. DOI: https://doi.org/10.1002/ajb2.1195

[20] W.B. Kippers, C.L. Poortman, K. Schildkamp, A.J. Visscher, Data Literacy: What Do Educators Learn and Struggle with during A Data Use Intervention?, Studies in Educational Evaluation 56 (2018) 21-31. DOI: https://doi.org/10.1016/j.stueduc.2017.11.001

[21] R. Bhargava, Data Literacy, Wiley \& Sons, 2019.

[22] M. Misbah, W.A. Pratama, S. Hartini, D. Dewantara, Pengembangan E-Learning Berbasis Schoology pada Materi Impuls dan Momentum untuk Melatihkan Literasi Digital, Pancasakti Science Education Journal 3(2) (2018) 109. DOI: https://doi.org/10.24905/psej.v3i2.1067 
[23] S. Thiagarajan, D.S. Semmel, M.I. Semmel, Instructional Development for Training Teacher of Expectional Children, ERIC, 1974.

[24] S. Ramadhan, D. Mardapi, Z.K. Prasetyo, H.B. Utomo, The Development of An Instrument to Measure the Higher Order Thinking Skill in Physics, European Journal of Educational Research 8(3) (2019) 743-751. DOI: https://doi.org/10.12973/eu-jer.8.3.743
[25] R.K. Hambleton, H. Swaminathan, Item Response Theory Principles and Applications, Spinger, Berlin, Heidelberg, 1985.

[26] D. Sands, M. Parker, H. Hedgeland, S. Jordan, R. Galloway, Using Concept Inventories to Measure Understanding, Higher Education Pedagogies 3(1) (2018)

173-182.

DOI: https://doi.org/10.1080/23752696.2018.1433546 